\title{
Investigation of the Pozzolanic Properties of Bricks Used in Horasan Mortars and Plasters in Historic Buildings
}

\author{
H. Böke ${ }^{1}$, S. Akkurt ${ }^{2}$ and B. İpekoğlu ${ }^{1}$ \\ ${ }^{1}$ Architectural Restoration Department, Izmir Institute of Technology, \\ Urla 35430 Izmir, Turkey \\ ${ }^{2}$ Mechanical Engineering Department, Izmir Institute of Technology, \\ Urla 35430 Izmir, Turkey
}

Keywords: Horasan Mortars, Plasters, Lime, Pozzolan, Historic Building,

\begin{abstract}
Crushed brick used in historic brick-lime mortars and plasters (Horasan) were characterized for understanding their properties to develop intervention mortars for conservation. Brick powders were separated from original mortars and plasters, and analyzed by XRD, SEMEDS, TGA and pozzolanic activity (PA) measurements. The results showed that the microstructures of brick powders were not completely vitrified, and their XRD analysis failed to show the peaks for high temperature $\left(\mathrm{T}>900^{\circ} \mathrm{C}\right)$ phases. PA measurements of all brick powders showed an ample amount of artificial pozzolan property. Consequently, brick powders aimed for conservation of historic mortars must have high clay contents in addition to being low-fired $\left(\mathrm{T}<900^{\circ} \mathrm{C}\right)$ in order to produce maximum conversion into amorphous phase for ideal PA values.
\end{abstract}

\section{Introduction}

Hydraulic lime mortars and plasters have been used in the construction of buildings, aqueducts, bridges and harbours since the Roman time [1]. They are made by mixing lime and natural or artificial pozzolans [2]. The natural pozzolans are mostly derived from volcanic rocks and certain diatomaceous earth. The artificial pozzolans are produced by heating clay minerals at temperatures of 600 to $900^{\circ} \mathrm{C}$ depending on the clay mineralogy. [3]. At such temperatures the structurally bound water in clay is driven off and the crystal structure collapses which results in an amorphous material (e.g.metakaolin) [4]. Bricks containing amorphous materials react with lime to produce calcium silicate hydrate $(\mathrm{CSH})$ and/or calcium aluminate hydrate $(\mathrm{CAH})$. The formation of these products leads to the high strength typical of these mortars and plasters [5].

Historic mortars and plasters need conservation due to their deterioration problems [6]. During the conservation work, the new mortars and plasters produced must be compatible with the existing ones. The use of present-day ground brick powders in the preparation of Horasan mortars and plasters for conservation purposes are unable to provide the above mentioned characteristics partly due to excessive firing temperatures [7] and partly owing to differences in clay minerals [3]. Therefore, the choice of appropriate bricks used in new intervention mortars and plasters is important. In this work, bricks used in Horasan mortars and plasters are examined to define their characteristics for potential use for conservation work. Samples from selected historic buildings were examined for this purpose.

\section{Materials and Method}

Horasan mortar and plaster samples were collected from three Ottoman bath buildings, from the $14^{\text {th }}$ and $15^{\text {th }}$ centuries, constructed in Edirne (Saray and Beylerbeyi) and Bursa (Ördekli), Turkey. The location and type of collected samples are listed in Table 1. 
All samples were sound and in good appearance without any sign of deterioration. The samples were first dissolved in dilute hydrochloric acid in order to remove the brick powder particles from the lime bonding phase. Thus, the proportions of lime and brick powders of mortars and plasters were determined after filtering and drying of the bricks. The pozzolanicity of the separated brick powders (less than 53 micrometers) were determined by mixing them in a saturated calcium hydroxide solution and by measuring the differences in electrical conductivity [8]. The mineralogical composition was determined by using Philips X-Pert X-Ray diffraction (XRD). The elemental composition and microstructure of the mortars, plasters and separated bricks were examined by a Philips XL-30-SFEG scanning electron microscope (SEM) coupled with EDS (EDAX Co). The TGA analyses of separated brick powders were carried out using a Shimadzu TGA - 21 thermogravimetric analyzer. TGA analyses were carried out in air and nitrogen atmosphere with a flow rate of $40 \mathrm{ml} / \mathrm{min}$ and a heating rate of $10^{\circ} \mathrm{C} \mathrm{min}^{-1}$ in the temperature range of $25-1000{ }^{\circ} \mathrm{C}$.

Table 1. Definition of Collected Samples and their Lime/Brick Ratios

\begin{tabular}{|c|c|c|c|}
\hline Sample* & Bath - City & Wall & Type \\
\hline S-Mor. & Saray - Edirne & Dome & Mortar \\
\hline B-Mor & Beylerbeyi -Edirne & Dome & Mortar \\
\hline S-Plas (D.H) & Saray -Edirne & Dressing hall & Plaster \\
\hline S-Plas (Tep.) & Saray -Edirne & Tepidarium & Plaster \\
\hline S-Plas (Cal.) & Saray-Edirne & Caldarium & Plaster \\
\hline Ö-Plas (Tep.) & Ördekli - Bursa & Tepidarium & Plaster \\
\hline O-Plas(1) (Cal.) & Ördekli - Bursa & Caldarium & Plaster \\
\hline O-Plas(2) (Cal.) & Ördekli - Bursa & Caldarium & Plaster \\
\hline B-Plas (Cal.) & Beylerbeyi -Edirne & Caldarium & Plaster \\
\hline ray $\quad \mathrm{B}=\mathrm{Be}$ & rbeyi $\quad \ddot{\mathrm{O}}=\mathrm{O} r \mathrm{rd}$ & ekli & or. $=\mathrm{Mo}$ \\
\hline
\end{tabular}

\section{Results and Discussion}

The physical characteristics like the relative proportions of brick powder and lime, chemical and thermal properties of separated brick powders, and microstructural characteristics of original mortar samples are presented in this section.

Lime/Crushed Brick Ratios of Mortars and Plasters and Pozzolanic Activities of the Bricks. The percent weight ratio of lime and crushed bricks, and the pozzolanic activities (PA) of the brick powders are shown in Fig.1. As can be seen in Fig.1, the binder/brick ratio was approximately 1/3 for mortars and 1/1 for plasters, confirming earlier findings [9]. In the literature, the pozzolanic activity values in excess of $1.2 \mathrm{mS} / \mathrm{cm}$ are regarded as good pozzolanicity [8]. The data in Figure 1, therefore showed satisfactory levels of pozzalonicity for all samples studied.

Thermal analysis of brick powders. TGA analysis of separated brick powders indicated two distinct weight losses around 100 and $400^{\circ} \mathrm{C}$. The first peak was due to the loss of hygroscopic water, while the second weak peak was dehydroxylation of clay minerals possibly present as a result of incomplete heating. Complete conversion of all clay minerals into amorphous phase (e.g.metakaolin) must have occurred for pozzalonic performance [3].

Microstructural, Mineralogical and Elemental Composition Analysis. Microstructures of polished sections and fracture surfaces of all mortar and plaster samples showed brick powder fragments firmly embedded in a lime based matrix. The needle like calcium silicate hydrate and calcium aluminium hydrate crystals are also observed at the brick-lime interface and inside the bricks as confirmed by EDS analysis (Fig. 2). These crystals provide cementitious bonding properties that result from the good pozzolanicity of bricks used in Horasan mortars and plasters. 
Elemental analysis indicated that the brick powders were largely composed of a high amount of silica, alumina and a moderate amount of iron and alkalies (Table 2). The relevant $\mathrm{SiO}_{2}-\mathrm{Al}_{2} \mathrm{O}_{3}$ $\mathrm{Na}_{2} \mathrm{O}$ phase diagram for these compositions can be used to predict that the vitrification temperatures were in the range of $800-1000^{\circ} \mathrm{C}$ [10]. Microstructure of brick powder (Fig.3) showed little vitrification suggesting a heating temperature at the lower end of the above temperature range $\left(\mathrm{T}<900^{\circ} \mathrm{C}\right)$. Their XRD results show strong peaks of quartz, feldspars and the diffuse band between 20-30 degrees for the amorphous phase (Table 2). Amorphous phases that are derived from heating the clay minerals, react with lime depending on the conditions different hydration reaction products such as calcium silicate hydrate and calcium aluminate hydrate may form [11]. These products formed at the lime-brick interface provide strong adhesion bonds which make the mortar durable and stiff.

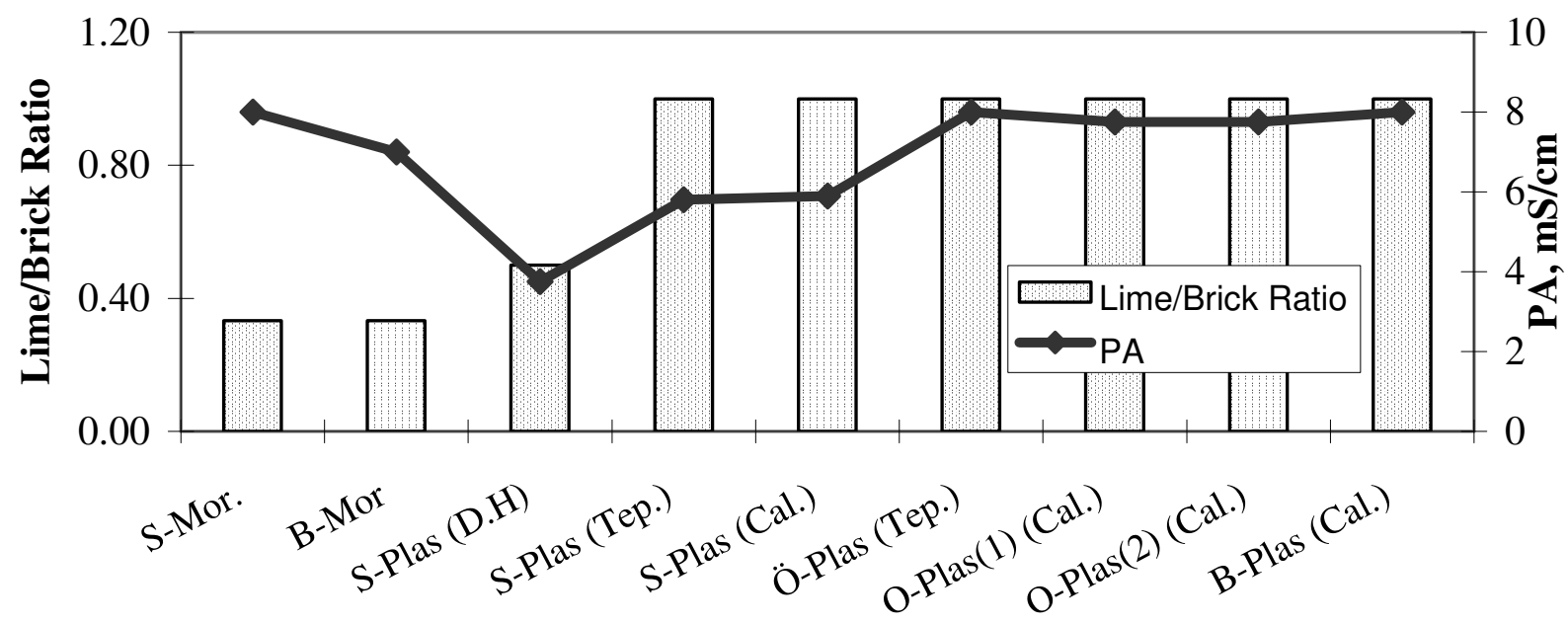

Figure 1. Pozzolanic activity values of the separated brick from mortars and plasters

Table 2. XRD Analysis and \% Elemental Composition Results of the Bricks used in Mortar and Plaster Samples

\begin{tabular}{|l|l|l|l|l|l|l|l|}
\hline Sample* & XRD* & $\mathrm{Na}_{2} \mathrm{O}$ & $\mathrm{K}_{2} \mathrm{O}$ & $\mathrm{MgO}$ & $\mathrm{Fe}_{2} \mathrm{O}_{3}$ & $\mathrm{Al}_{2} \mathrm{O}_{3}$ & $\mathrm{SiO}_{2}$ \\
\hline S-Mor. & Q, F, AP & 2.97 & 2.09 & 2.54 & 13.83 & 9.27 & 69.3 \\
\hline B-Mor & Q, F, I & 3.41 & 2.38 & 1.74 & 10.12 & 9.34 & 73.01 \\
\hline S-Plas (D.H) & Q, F, AP & 5.83 & 8.21 & 4.44 & 8.99 & 14.28 & 58.29 \\
\hline S-Plas (Tep.) & Q, F, AP & 1.53 & 1.24 & 1.89 & 6.25 & 8.36 & 80.73 \\
\hline S-Plas (Cal.) & Q, F, AP & 1.79 & 1.42 & 1.71 & 5.88 & 9.40 & 79.81 \\
\hline Ö-Plas (Tep.) & Q, F, AP & 2.97 & 3.43 & 5.52 & 14.85 & 20.86 & 52.37 \\
\hline O-Plas(1) (Cal.) & Q, F, AP & 0.92 & 0.68 & 2.92 & 10.33 & 9.00 & 76.15 \\
\hline O-Plas(2) (Cal.) & Q, F, AP & 1.93 & 2.05 & 5.47 & 10.99 & 21.36 & 58.19 \\
\hline B-Plas (Cal.) & Q, F, AP & 3.21 & 12.35 & 6.22 & 9.97 & 15.24 & 53.01 \\
\hline
\end{tabular}

$\mathrm{Q}=$ Quartz $\mathrm{F}=$ Feldspar $\mathrm{AP}=$ Amorphous PhaseI=Illite 


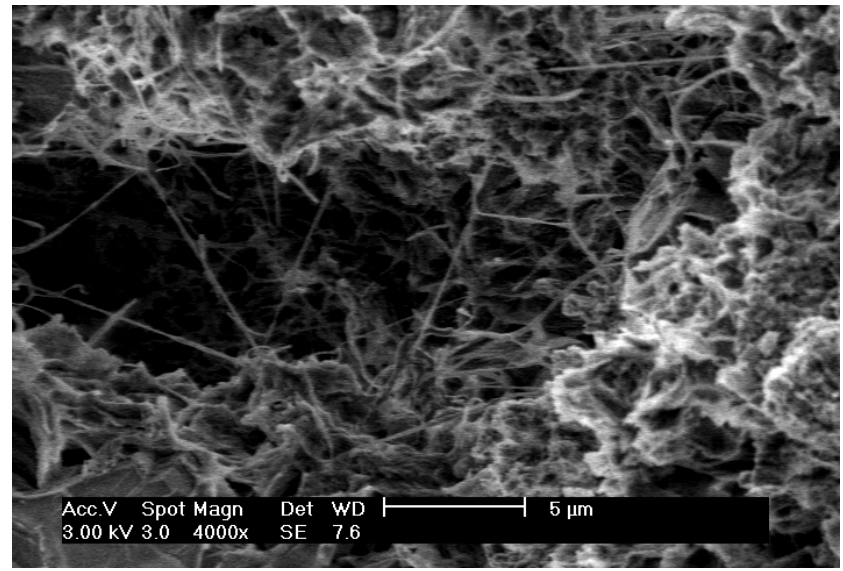

Figure 2. Secondary electron image of needlelike calcium silicate hydrate and calcium aluminate hydrate crystals. (S-Mor)

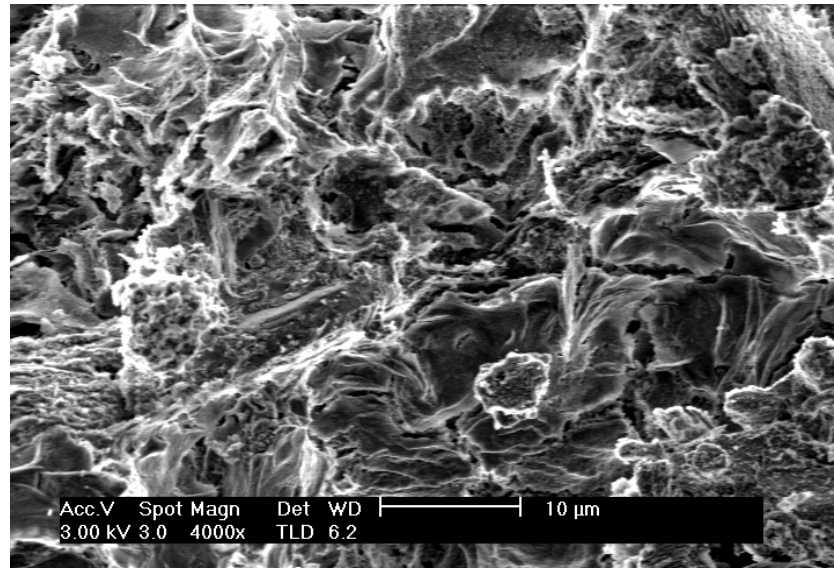

Figure 3. Secondary electron image of low or non glassy phase of bricks. (S-Mor)

\section{Conclusions}

Historic Horasan mortars and plasters from bath buildings have survived to present day without significant deterioration. This shows that crushed brick-lime mortars and plasters had been ideal cementing materials, especially for the moist and hot environment of the baths.

This work shows that the bricks used in Horasan mortars and plasters have good pozzolanicity derived from amorphous clay mineral dissociation products (e.g.metakaolin). Microstructural analysis of the separated brick samples indicated the presence of little vitrification. XRD studies showed no peaks for high temperature forms like mullite, suggesting the low firing temperatures. Phase diagrams also agreed with the predicted temperature levels.

Present-day bricks used in the preparation of new Horasan mortars and plasters are rarely pozzolanic because they are fired at high temperatures $\left(\mathrm{T}>900^{\circ} \mathrm{C}\right)$ making them inappropriate for the preparation of the new intervention mortar and plaster for the conservation work. The bricks used in the preparation of Horasan mortars and plasters must have a high amount of clay minerals and must be fired at low temperatures of $600-900{ }^{\circ} \mathrm{C}$.

\section{Acknowledgments}

This work was supported by the research grants of IÇTAG-I674 (TÜBİTAK).

\section{References}

[1] A. Moropoulou, A. Bakolas, K. Bisbikou: Thermochim. Acta Vol. 269/270 (1995), p. 779

[2] F.M. Lea: Buil. Res. Tech. Paper No.27 (1940)

[3] C. He, B. Osbaeck and E. Makovicky: Cem. Concr. Research Vol. $25-8$ (1995), p. 1691

[4] S. Lee, Y.J. Kim, H. Moon: Jour. Am. Cer. Society Vol.82 (1999), p. 2841

[5] A. Moropoulou, A.S. Çakmak, G. Biscontin, A.Bakolas, E. Zendri: Cons. Buil. Materials Vol.16 (2002) p. 543

[6] H.Boke and S. Akkurt: Cem. Concr. Research (2003) In press.

[7] G. Baronia and Luigia Binda: Cons. Buil. Materials Vol.11- 1 (1997), pp. 41-46,

[8] M.P. Luxan, F. Madruga and J. Saavedra: Cem. Concr. Research Vol. 19 (1989), p. 63

[9] A. Moropoulou, A. Bakolas, K. Bisbikou: Cons. Buil. Materials Vol. 14 (2000), p. 35

[10] E. M. Lewin, H.F. McMurdie, F.P. Hall: Phase Diagrams for Ceramists (American Ceramic Society, Columbus 1956)

[11] W. Prince, G.Castainier, J. L. Giafferi: Cem. Concr. Research Vol. 31 (2001), p. 271 


\section{Euro Ceramics VIII}

10.4028/www.scientific.net/KEM.264-268

Investigation of the Pozzolanic Properties of Bricks Used in Horasan Mortars and Plasters in Historic Buildings

10.4028/www.scientific.net/KEM.264-268.2399

\section{DOI References}

[1] A. Moropoulou, A. Bakolas, K. Bisbikou: Thermochim. Acta Vol. 269/270 (1995), p. 779 10.1016/0040-6031(95)02573-1 